\title{
Note: the effect of parasite infection on the innate immune response of European flounder (Platichthys flesus L.) in the southern North Sea
}

Received: 11 November 2002 / Revised: 3 February 2003 / Accepted: 24 February 2003 / Published online: 26 April 2003 (C) Springer-Verlag and AWI 2003

\begin{abstract}
In a field study, infecting European flounder (Platichthys flesus L.) subclinically with different parasite species did not result in any alteration of the innate immune response. Due to the high variability in infection status and the immune parameters measured, no relationships of biological significance were found. The data indicate that copepods, as the most abundant parasites, most probably had no major influence on immune responses measured here. Thus it might be concluded that these parameters were not sensitive to parasite infections occurring under natural conditions. The immune parameters considered here are regarded as promising indicators of chemical contaminant-induced variation in piscine immune responses, which could be implemented in pollution monitoring programmes.
\end{abstract}

Keywords Innate immune response $\cdot$ Parasites $\cdot$ North Sea $\cdot$ Flounder

\section{Introduction}

Worldwide, the aquatic environment is abused by the introduction of a high number of xenobiotic compounds derived from human activities in industry and agriculture. Many of these substances have the potential to impact on the ecosystem at relatively low concentrations (Conell et al. 1999). In order to assess the risk of contaminant exposure for organisms, and to classify the environmental health of an ecosystem under challenge, innate immune responses in fish are recommended as bioindicators of xenobiotic exposure (Bols et al. 2001). In laboratory or mesocosm studies, the immunomodulatory potential of a wide variety of compounds, such as hydrocarbons or heavy metals, has been assessed [for review see Dunier

Communicated by H. v. Westernhagen, A. Diamant

A. Skouras · V. Schmidt · W. Körting · D. Steinhagen ( Fish Disease Research Unit, School of Veterinary Medicine, P.O. Box 711180, 30545 Hannover, Germany e-mail: Dieter.Steinhagen@tiho-hannover.de and Siwicki (1993); Zelikoff et al. (2000)]. In these experiments, hatchery- or laboratory-raised fish of known health status were exposed to specific compounds at defined concentrations for a limited period of time [e.g. Zelikoff et al. (2000); for review see Bols et al. (2001)]. In 'real world' monitoring programmes, fishes were collected at coastal or marine sites for an assessment of effects of a largely unknown mixture of contaminants (Secombes et al. 1997; Zelikoff et al. 1997). In many cases, biomarker responses varied within wide ranges, which made interpretation of biological effects difficult. Besides genetic heterogenicity, some variation might originate from differences in life history and parasite infection in individuals examined. In coastal or marine environments, most fish individuals harbour a very diverse parasite fauna (Overstreet et al. 1997; Broeg et al. 1999; Schmidt et al. 2003), and infections with some species might result in a modulation of physiological or immune responses (Overstreet 1997), which are considered as indicators of biological effects of environmental contaminants. In most studies carried out in the past, physiological or innate immune response were only evaluated with regard to chemical residues found in the fish or at the sample site (Tahir et al. 1993; Secombes et al. 1995, 1997) and nonpathogenic infections, with parasites for instance, were not considered. In an integrated biological effect monitoring programme on flounder, Platichthys flesus, in addition to some innate immune responses, the parasite fauna of the same individuals was assessed (Schmidt et al. 2003; Skouras et al. 2003). This allowed a correlation of immunological measurements to the parasitological findings.

\section{Methods}

Sampling

In April and September 1999 and 2000, a total of 331 flounder $(P$. flesus L.) were collected at five different locations in the German Bight (Elbe estuary, Inner Eider estuary, Outer Eider, Spiekeroog and Tiefe Rinne near Helgoland), during cruises with the research 
Table 1 Summary of the number of flounder (Platichthys flesus) caught for the analysis of innate immune parameters and parasites in 1999-2000. All parameters were measured from the same individual

\begin{tabular}{lclll}
\hline Site & $\begin{array}{l}\text { Spring } \\
1999\end{array}$ & $\begin{array}{l}\text { Autumn } \\
1999\end{array}$ & $\begin{array}{l}\text { Spring } \\
2000\end{array}$ & $\begin{array}{l}\text { Autumn } \\
2000\end{array}$ \\
\hline Elbe & 20 & 20 & 20 & 20 \\
Spiekeroog & 9 & 20 & 9 & 20 \\
Helgoland & 20 & 20 & 20 & 20 \\
Inner Eider & 15 & - & 18 & - \\
Outer Eider & 19 & 20 & 20 & 20 \\
\hline
\end{tabular}

vessel "Uthörn" of the Alfred Wegener Institute. Details of sampling, examination of the flounder and collection of parasites have been described elsewhere (Schmidt et al. 2003; Skouras and Steinhagen 2003). For analysis, only macroscopically healthy flounder of the size class $18-25 \mathrm{~cm}$ were used. Table 1 shows the number of individuals analysed at the sampling site during all sampling periods.

\section{Examination procedure}

On board the research vessel, body length and weight of each fish were measured, and macroscopic visible ectoparasites were collected. Blood was drawn from the caudal vein into disposable syringes pre-filled with a lithium-heparin bead (Sarstedt, Germany). From the blood, the haematocrit was determined according to standard procedures (Houston 1990). The remaining blood was then transferred to centrifugation tubes, centrifuged at 2,000 $\mathrm{g}$ for $15 \mathrm{~min}$ at $4^{\circ} \mathrm{C}$, and the supernatant plasma was collected and frozen at $-80^{\circ} \mathrm{C}$. Then the fish was killed, dissected and the head kidney was removed and transferred into a centrifugation tube filled with wash medium (RPMI medium supplemented with 10,000 IU ${ }^{-1}$ sodium heparin, medium: Biochrom, Berlin, Germany, heparin: Sigma St. Louis, Mo.) and stored at $4^{\circ} \mathrm{C}$ for up to $24 \mathrm{~h}$ for further processing. In addition liver, kidney, intestine, gills and muscle samples were collected for parasitological, physiological and biochemical research as well as residual analysis (Dizer et al. 2003; Schmidt et al. 2003). From the morphological measurements, a whole body condition factor $(\mathrm{CF})$ was determined for each fish according to the formula: $\mathrm{CF}=$ body weight in $\mathrm{g} \times$ (body length in $\mathrm{cm})^{-3}$ and used as an allometric index for overall health (Busacker et al. 1990).

\section{Parasitological examination}

On board, the flounder were examined for ectoparasites. Specimens were collected from the skin and stored in $70 \%$ ethanol for further counting and identification. Fresh smears were taken from skin, gills, nose cavity, and gut and gall bladder epithelium and immediately examined for the presence of parasites by light microscopy. Then the fish were killed and dissected. Gills then were fixed in $4 \%$ buffered $(\mathrm{pH} 7.2)$ formaldehyde solution. The gut was removed, opened and transferred to saline solution $(0.9 \%$ $\mathrm{NaCl}$ ) and a drop of detergent was added. Under these conditions, parasites detached from the intestinal tissue and settled at the bottom of the vial. Then the supernatant fraction was discarded, the sediment resuspended in saline and again allowed to settle for a few minutes. After three washes, organic waste was removed from the gut contents. The remaining parasites were fixed in $70 \%$ ethanol for further investigation. Then gut, kidney, gall bladder and gills were fixed in $4 \%$ buffered formaldehyde solution. Transverse sections of mid- and hind-gut, as well as small parts of the kidney, were taken for histological investigation. Gills, gut and gut contents were examined for metazoan parasites with a dissection microscope. Parasites were collected, counted and stored separately for individual fish. Sections of gut and kidney were processed by standard histological procedures (Romeis 1989), stained by Giem- sa's technique and examined with a light microscope for tissue invading parasites.

To identify the macroparasites, individuals were cleared in 80 90\% lactic acid, mounted in glycerine-jelly and observed with the microscope. Smears of Trichodina spp. were air dried and stained by Klein's silver impregnation method (Lom and Dyková 1992).

Parasites were identified using standard literature (Yamaguti 1959, 1963a, 1963b, 1971; Kabata 1979) and with support from Dr. M. Køie (Marine Laboratory, Helsing ør, Denmark) for trematodes, cestodes and acanthocephalans and from Dr. F. Moravec (Institute of Parasitology, Ceské Budejovice, Czech Republic) for nematodes.

For all parasites, the prevalence at the sampling site was calculated. In addition, infection parameters such as intensity and abundance of countable parasites were calculated according to Busch et al. (1997).

\section{Lysozyme assay}

Lysozyme activity of flounder plasma was determined by means of a turbidimetric assay according to Parry et al. (1965). A suspension of $0.2 \mathrm{~g}^{-1}$ Micrococcus lysodeikticus (Sigma-Aldrich, Germany) in $0.05 \mathrm{M}$ sodium phosphate buffer ( $\mathrm{pH}$ 6.2) was mixed with $25 \mu \mathrm{l}$ flounder plasma to give a final volume of $200 \mu \mathrm{l}$ per well. The optical density was read in a spectrophotometer at $530 \mathrm{~nm}$ immediately after mixing, after $0.5 \mathrm{~min}$ and after $4.5 \mathrm{~min}$ at a temperature of $20 \pm 2^{\circ} \mathrm{C}$. The decrease in absorbance was used to calculate lysozyme activity. One unit of lysozyme activity is defined as the amount of sample causing a decrease in absorbance of $0.001 \mathrm{~min}^{-1}$. Hen white egg lysozyme (Sigma-Aldrich, Germany) was used as the external standard as described by Hutchinson and Manning (1996).

\section{Leucocyte isolation}

Leucocyte isolation was done as described previously (Skouras and Steinhagen 2003). Briefly, cell suspensions of head kidney leucocytes (HKL) were prepared by forcing the tissues through a $100 \mu \mathrm{m}$ nylon screen (Swiss Silk Bolting Cloth Mfg, Zurich, Switzerland). Isolated HKL were washed three times with wash medium at $550 \mathrm{~g}$ for $10 \mathrm{~min}$ and resuspended in cell culture medium (RPMI-1640 supplemented with 100,000 $\mathrm{IU} \mathrm{l}^{-1}$ penicillin, $100 \mathrm{mg} \mathrm{l}^{-}$ ${ }^{1}$ streptomycin and $4 \mathrm{mM} \mathrm{L-glutamine}$ and $1 \%$ [v/v] carp serum (chemicals: Biochrom, Berlin, Germany; carp serum: serum from 15 individual Cyprinus carpio L. was pooled, heat inactivated for $30 \mathrm{~min}$ at $56^{\circ} \mathrm{C}, 0.2 \mu \mathrm{m}$ filtered and stored at $-20^{\circ} \mathrm{C}$ until use). Numbers of viable cells were determined by trypan blue exclusion in a Neubauer haemocytometer.

Production of reactive oxygen species by HKL

Generation of reactive oxygen species (ROS) by HKLwas measured by means of the nitro blue tetrazolium salt (NBT) reduction assay after cell isolation, as described earlier (Skouras and Steinhagen 2003). Briefly, cells were incubated in 96-well flatbottom microtitre plates $\left(10^{6}\right.$ cells in a final volume of $175 \mu \mathrm{l}$ cell culture medium) in triplicate and their ROS production was induced by adding $0.15 \mathrm{mg}^{-1}$ phorbolmyristate acetate (PMA). The indicator NBT was added at $1 \mathrm{~g} \mathrm{l}^{-1}$. Wells without PMA served to determine the spontaneous ROS generation of cells. After incubation for $2 \mathrm{~h}$ at $18^{\circ} \mathrm{C}$, the supernatants were removed and the cells were fixed by adding $125 \mu \mathrm{l}$ of $100 \%$ methanol. Each well was washed twice with $125 \mu \mathrm{l} 70 \%$ [v/v] methanol. Methanol was removed and the fixed cells were air dried overnight and stored in the dark for up to 2 weeks. The reduced NBT (formazan) was dissolved in $125 \mu \mathrm{l}$ of $2 \mathrm{M} \mathrm{KOH}$ and $150 \mu \mathrm{l}$ DMSO per well (all chemicals: Sigma-Aldrich, Germany). The optical densities were recorded with a spectrophotometer at $650 \mathrm{~nm}$. 
Endocytosis activity of head kidney phagocytes

Endocytosis activity of head kidney phagocytes was measured by means of neutral red retention of isolated head kidney cells as described by Matthews et al. (1990). This assay was adapted to microtitre plates. Briefly, $10^{6}$ cells were incubated in a final volume of $175 \mu \mathrm{l}$ culture medium for $2.5 \mathrm{~h}$ at $18^{\circ} \mathrm{C}$ with $10 \mathrm{mg} \mathrm{l}^{-1}$ neutral red (NR, Sigma-Aldrich, Germany). All set-ups were made at least in triplicate. After incubation, each well was washed twice with $125 \mu$ phosphate-buffered saline (PBS). After removing the PBS, the cells were air dried overnight and frozen at $-20^{\circ} \mathrm{C}$ for up to 2 weeks. For spectrophotometric readings, the cells were lysed with $100 \mu \mathrm{l}$ acid ethanol (3\% $\mathrm{HCl}$ in $95 \%$ ethanol) and mixed with $100 \mu \mathrm{l}$ PBS. The optical densities were recorded at $492 \mathrm{~nm}$.

Statistics

Normality of the data was tested using the Kolmogorov-Smirnow test. To determine the significance between groups, data were compared using the Student's $t$-test, Mann-Whitney's rank sum test when the test for normality failed, or the Kruskal-Wallis ANOVA and subsequent multiple comparison by means of the StudentNewman-Keuls method at a probability of error $P<0.05$. Correlations between data sets were tested using Pearson's product moment correlation test or Spearman's rank correlation test, when the test for normality failed. Correlations were considered as significant at a probability of error $P<0.05$. The analyses were carried out using SigmaStat 2.0 and STATISTICA 6 (StatSoft) software packages. For correlations, data of parasite abundance were compared to immunological measurements.

\section{Results and discussion}

A total of 28 parasite species/taxa were recorded during the sampling campaigns in 1999 and 2000. Out of these, 17 species/taxa were present at all sampling sites, but not all of them were found during both seasons or during each sampling campaign. A list of the parasites, their prevalence and mean abundance is shown in Table 2, for details see Schmidt et al. (2003). Only seven species/taxa were regularly present over the whole sampling period: the Ciliophora Trichodina spp., the copepods Acanthochondria cornuta, Lepeophtheirus pectoralis and Lernaeocera branchialis, the helminths Zoogonoides viviparus and Cucullanus heterochrous, and undetermined metacercaria in the gills. Species of Microsporea, Myxozoa and Apicomplexa, which previously were reported to influence immune responses in fish (Munoz et al. 1998, 2000; Leiro et al. 2001), were also considered for analysis.

The presence or absence of parasites had some impact on several of the innate immune parameters measured here, but the pattern varied with the single parasite species (Table 3). Individuals with Trichodina sp. infection had reduced plasma lysozyme levels with 990 (767-1348) IU $\mathrm{ml}^{-1}$ compared to $1,172(892-1519) \mathrm{IU} \mathrm{ml}^{-1}$ in noninfected fish. In flounder with a renal myxosporidian infection (Myxozoa sp. 1), the basal ROS production was decreased, with $0.039(0.025-0.143)$ OD values compared to $0.093(0.044-0.262)$ in unaffected individuals. In individuals with high copepod load (more than 20
Table 2 List of parasite species, target organ/tissue, prevalence and abundance in flounder (P. flesus) in the German Bight during sampling campaigns in spring and autumn 1999-2000. Abundance data are given for all countable parasite species

\begin{tabular}{|c|c|c|c|c|}
\hline $\begin{array}{l}\text { Taxonomic } \\
\text { group }\end{array}$ & Parasite species & $\begin{array}{l}\text { Target } \\
\text { organ/ tissue }\end{array}$ & Prevalence & Abundance \\
\hline Apicomplexa & Epieimeria sp. & Gut & $24.3 \pm 20.1$ & \\
\hline Ciliophora & Trichodina spp. & Gills & $54.2 \pm 31.8$ & \\
\hline Microsporea & $\begin{array}{l}\text { Microsporea sp. } 1 \\
\text { Glugea stephani }\end{array}$ & $\begin{array}{l}\text { Kidney } \\
\text { Gut }\end{array}$ & $\begin{array}{c}30.3 \pm 10.3 \\
0.7 \pm 2.0\end{array}$ & \\
\hline Myxozoa & $\begin{array}{l}\text { Myxozoa sp. } 1 \\
\text { Myxidium incurvatum }\end{array}$ & $\begin{array}{l}\text { Kidney } \\
\text { Gall bladder }\end{array}$ & $\begin{array}{r}9.5 \pm 11.0 \\
23.6 \pm 17.5\end{array}$ & \\
\hline Digenea & $\begin{array}{l}\text { Derogenes varicus } \\
\text { Brachyphallus crenatus } \\
\text { Zoogonoides viviparus } \\
\text { Lecithaster gibbosus } \\
\text { Podocotyle atomon } \\
\text { Metacercaria sp. } 1\end{array}$ & $\begin{array}{l}\text { Gut } \\
\text { Gut } \\
\text { Gut } \\
\text { Gut } \\
\text { Gut } \\
\text { Gills }\end{array}$ & $\begin{array}{c}6.0 \pm 9.0 \\
4.5 \pm 6.6 \\
17.1 \pm 27.2 \\
1.5 \pm 3.2 \\
5.6 \pm 7.5 \\
60.7 \pm 22.6\end{array}$ & $\begin{array}{l}0.1 \pm 0.4 \\
0.2 \pm 2.1 \\
9.3 \pm 34.7 \\
0.01 \pm 0.1 \\
0.2 \pm 1.6 \\
32.0 \pm 106.8\end{array}$ \\
\hline Cestoda & $\begin{array}{l}\text { Bothriocephalus spp. } \\
\text { Proteocephalus sp. } \\
\text { Cestoda larvae sp. } 2\end{array}$ & $\begin{array}{l}\text { Gut } \\
\text { Gut } \\
\text { Gut }\end{array}$ & $\begin{array}{l}0.8 \pm 1.9 \\
0.8 \pm 2.6 \\
0.3 \pm 1.2\end{array}$ & $\begin{array}{l}0.01 \pm 0.1 \\
0.04 \pm 0.5 \\
0.02 \pm 0.3\end{array}$ \\
\hline Nematoda & $\begin{array}{l}\text { Paracapillaria gibsoni } \\
\text { Cucullanus heterochrous } \\
\text { Dichelyne minutus } \\
\text { Goezia sp. }\end{array}$ & $\begin{array}{l}\text { Gut } \\
\text { Gut } \\
\text { Gut } \\
\text { Gut }\end{array}$ & $\begin{array}{c}16.6 \pm 17.1 \\
46.2 \pm 20.8 \\
5.8 \pm 8.3 \\
1.4 \pm 3.8\end{array}$ & $\begin{array}{l}2.6 \pm 14.1 \\
1.5 \pm 3.2 \\
0.1 \pm 0.3 \\
0.03 \pm 0.2\end{array}$ \\
\hline Acanthocephala & $\begin{array}{l}\text { Hysterothylacium aduncum } \\
\text { Corynosoma sp. } \\
\text { Echinorhynchus gadi } \\
\text { Pomphorhynchus laevis }\end{array}$ & $\begin{array}{l}\text { Gut, liver } \\
\text { Gut } \\
\text { Gut } \\
\text { Gut }\end{array}$ & $\begin{array}{l}12.9 \pm 12.0 \\
3.7 \pm 4.2 \\
3.8 \pm 12.0 \\
0.4 \pm 1.6\end{array}$ & $\begin{array}{l}0.3 \pm 2.1 \\
0.1 \pm 0.4 \\
0.1 \pm 0.3 \\
0.1 \pm 1.3\end{array}$ \\
\hline Copepoda & $\begin{array}{l}\text { Acanthochondria cornuta } \\
\text { Caligus elongatus } \\
\text { Holobomolochus confusus } \\
\text { Lernaeocera branchialis } \\
\text { Lepeophtheirus pectoralis }\end{array}$ & $\begin{array}{l}\text { Gill cavity } \\
\text { Skin } \\
\text { Nose cavity } \\
\text { Gills } \\
\text { Skin, fins }\end{array}$ & $\begin{array}{c}67.8 \pm 28.1 \\
4.8 \pm 10.2 \\
3.9 \pm 7.4 \\
95.0 \pm 15.4 \\
76.3 \pm 27.7\end{array}$ & $\begin{array}{c}5.3 \pm 6.4 \\
0.1 \pm 0.9 \\
0.1 \pm 0.9 \\
58.3 \pm 55.9 \\
8.1 \pm 7.8\end{array}$ \\
\hline
\end{tabular}


Table 3 Comparison of the presence of parasites in flounder ( $P$. flesus) and immunological parameters measured from the same individuals. The flounder were collected in 1999-2000 from five different locations in the German Bight, North Sea. Immune parameters of affected flounder were compared to measurements obtained from non-infected individuals by means of the MannWhitney rank sum test. Listed are $P$ values obtained from the test. For sum copepoda and sum helminth, correlations were conducted. The Spearman rank correlation coefficient is shown. Statistically

\begin{tabular}{llllll}
\hline Parasite & Haematocrit & Lysozyme & Pinocytosis & Basal ROS & PMA activated ROS \\
\hline Microsporea & 0.75 & 0.06 & 0.34 & 0.83 & 0.89 \\
Trichodina spp. & 0.95 & $\mathbf{0 . 0 2}(-)$ & 0.12 & 0.17 & 0.14 \\
Myxdium incurvatum & 0.41 & 0.07 & 0.43 & 0.14 & 0.56 \\
Myxozoa sp. 1 & 0.26 & 0.14 & 0.24 & $<.01(-)$ & 0.25 \\
Sum Copepoda & 0.01 & $\mathbf{0 . 1 2}$ & 0.11 & 0.02 & 0.10 \\
Sum helminths & 0.09 & $\mathbf{0 . 1 9}$ & 0.02 & 0.11 & \\
\hline
\end{tabular}

significant differences in the immune response between the groups at $P<0.05$ are marked in bold. $(+)$ : increased immune parameter in infected flounder; $(-)$ : depressed immune parameter in infected individuals. $n=286-330$; Microsporea: Glugea stephani; Microsporea sp 1 (kidney); Sum Copepoda: sum of Acanthochondria cornuta, Caligus elongus, Holobomolochus confusus, Lerneocera branchialis, Lepeophtheirus pectoralis; Sum helminths: sum all of

Digenea, Cestoda, Nematoda and Acanthocephala

Table 4 Multiple linear regressions between parasites in flounder ( $P$. flesus) and the immune parameters measured in the same individuals. The presence of parasites is tested as explaining variable on the immune responses applied here. The $P$ values obtained from the calculation are given. An influence was considered to be significant at $P<0.05^{*} ; P<0.001 * *$. $n=286-330$. Apicomplexa: Epieimeria sp.; Microsporea: Glugea stephani;

Microsporea sp. 1 (kidney); Ciliophora:Trichodina spp.; Myxozoa: Myxidium incurvatum, Myxozoa sp. 1 (kidney); Sum Copepoda: sum of Acanthochondria cornuta, Caligus elongus, Holobomolochus confusus, Lernaeocera branchialis, Lepeophtheirus pectoralis; Sum helminths: sum of Digenea, Cestoda, Nematoda and Acanthocephala

\begin{tabular}{lccccc}
\hline Parasite & Haematocrit & Lysozyme & Pinocytosis & ROS & PMA activated ROS \\
\hline Apicomplexa & 0.67 & 0.85 & $<0.01^{*}$ & $<0.01^{*}$ & 0.09 \\
Microsporea & 0.21 & 0.14 & 0.21 & 0.44 & 0.93 \\
Ciliophora & 0.75 & 0.30 & 0.12 & 0.81 & 0.37 \\
Myxozoa & 0.34 & 0.34 & 0.19 & 0.23 & 0.12 \\
Sum Copepoda & 0.89 & 0.14 & $0.02^{*}$ & 0.60 & 0.52 \\
Sum helminths & $<0.01^{*}$ & $<0.01^{* *}$ & 0.35 & 0.77 & 0.12 \\
\hline
\end{tabular}

copepods per fish, $n=246$ ), the plasma lysozyme activity and the basal and PMA-triggered ROS production of HKL were increased. Individuals with high copepod load had a plasma lysozyme activity of $1,128(856-1,461) \mathrm{IU}$ $\mathrm{ml}^{-1}$, a basal ROS production of $0.0965(0.045-0.261)$ OD and a PMA stimulated ROS production of $0.342(0.215-$ $0.590)$ OD. In individuals with low copepod load $(<20$ copepods, $n=56$, the lysozyme activity was 875 (6021,234) $\mathrm{IU} \mathrm{ml} \mathrm{ml}^{-1}$, and the respiratory burst activity was $0.057(0.029-0.181)$ OD and $0.216(0.103-0.368)$ OD, respectively.

In individuals with renal microsporidian infections (Myxozoa sp. 1) or with Myxidium incurvatum, the innate immune responses monitored here appeared not to be affected when compared to measurement from individuals not infected by these parasites.

High infections with helminths, calculated as the sum of all gut-dwelling helminth parasites such as digeneans, cestodes, nematodes and acanthocephalans, an impact on the innate immune response measured here was calculated $(r=0.19, \quad P<0.05)$, but when the data plots for this relationship were analysed, a clear correlation could not be visualized. The majority of the flounder harboured low numbers of helminths only. In these individuals, the measurements of the immunological parameters already varied over the whole range. This picture applied to other parasites in this study as well. The majority of the flounder carried low infections and, in these individuals, the measurements of immune parameters varied in the same ranges as observed for flounder with high parasite loads. These findings indicate that, in the flounder examined here, a sub-clinical parasite infection most likely had little impact on the assessed immune parameters. This assumption was also supported by a multiple regression analysis (Table 4). When parasite abundance was considered as an influencing factor on the immune parameters applied here, haematocrit $(P<0.01)$ and the plasma lysozyme activity $(P<0.001)$ appeared to be mainly affected by the presence of gut-dwelling helminths while head kidney phagocytes (pinocytosis and basal respiratory burst activity, $P<0.01$ ) were found to be mainly influenced by the presence of an Epieimeria infection (Table 4, cited as Apicomplexa). It was surprising that parasites with low prevalence and/or abundance such as Epieimeria or the sum of helminths appeared as significant explaining factors in a multiple regression analysis while copepods, as the most abundant parasite group, seemed to play a minor role as an influencing factor on the innate immune responses measured here (see Table 4).

Taken together, the data presented here suggest that the sub-clinical parasite load of flounder caught from a marine site has no major modulating impact on innate immune functions of the individual. Thus, when these 
immune parameters are considered as biomarkers for the immunomodulatory potential of environmental contaminants, sub-clinical parasite infections most probably will not affect the measurements. We are aware that this only is true for those parasites found here and not for other pathogens such as bacteria, viruses or fungi. In the present investigation, most pathogenic species were excluded by selecting externally healthy individuals only. In conclusion, for an assessment of the immunomodulatory potential of environmental contaminants, clinically healthy fish with parasite infections show little alteration of innate immune responses.

Acknowledgements The authors would like to thank M. Borchardt, W. Hedderich, F. Lüders, S. Maurer, H. Nachtweh and S. Rudat for technical assistance in sample collection and processing. We also thank Captain C. Lührs and his crew on the R.V. "Uthörn" for their never-ending efforts in sampling the flounder, the AWI/Biologische Anstalt Helgoland for providing laboratory facilities on the island of Helgoland and our colleagues from other working groups of the MARS framework for fruitful co-operation. This study was supported by the German Ministry of Education and Science in the MARS framework (BMBF code 03F0159A).

\section{References}

Bols NC, Brubacher JL, Ganassin RC, Lee LEJ (2001) Ecotoxicology and innate immunity in fish. Dev Comp Immunol 25:853-873

Broeg K, Zander S, Diamant A, Körting W, Krüner G, Paperna I, Westernhagen $\mathrm{H}$ von (1999) The use of fish metabolic, pathological and parasitological indices in pollution monitoring. I. North Sea. Helgol Mar Res 53:171-194

Busacker GP, Adelman IR, Goolish EM (1990) Growth. In: Schreck CB, Moyle PB (eds) Methods for fish biology. American Fisheries Society, Bethesda, Md., pp 363-387

Bush AO, Lafferty KD, Lotz JM, Shostak AW (1997) Parasitology meets ecology on its own terms: Margolis et al. revisited. J Parasitol 83:575-583

Connell D, Lam P, Richardson B, Wu R (1999) Introduction to ecotoxicology. Blackwell, Oxford

Dizer H, Fischer B, Bressler V, Unruh E, Krüner G, Broeg K, Westernhagen $\mathrm{H}$ von, Levikov S, Baumert H, Hansen PD (2003) Neurotoxic, genototix, immunotoxic and endocrine effects of fish and molluscs in the North Sea, Mediterranean Sea and Red Sea. Helgol Mar Res (in press)

Dunier M, Siwicki AK (1993) Effects of pesticides and other organic pollutants in the aquatic environment on immunity of fish: a review. Fish Shellfish Immunol 3:423-438

Houston AH (1990) Blood and circulation. In: Schreck CB, Moyle PB (eds) Methods for fish biology. American Fisheries Society, Bethesda, Md., pp 273-334

Hutchinson TH, Manning MJ (1996) Seasonal trends in serum lysozyme activity and total protein concentration in dab (Limanda limanda L.) sampled from Lyme Bay, UK. Fish Shellfish Immunol 6:473-482

Kabata Z (1979) Parasitic Copepoda of British fish. The Ray Society 152, London, pp 1-468

Leiro J, Iglesias R, Parama A, Sanmartin ML, Ubeira (2001) Effect of Tetramicra brevifilum (Microspora) infection on respiratoryburst responses of turbot (Scophthalmus maximus L.) phagocytes. Fish Shellfish Immunol 11:639-652

Lom J, Dyková I (1992) Protozoan parasites of fishes. Elsevier, Amsterdam
Matthews ES, Warinner JE, Weeks BA (1990) Assay of immune function in fish macrophages: techniques used as indicators of environmental stress. In: Stolen JS, Fletcher DP, Anderson DP, Robertson BS, Muiswinkel WB van (eds) Techniques in fish immunology. SOS Publications, Fair Haven, N.J., pp 155-163

Munoz P, Calduch-Giner JA, Sitja-Bobadilla, Alvarez-Pellitero P, Perez-Sanchez J (1998) Modulation of the respiratory burst activity of Mediterranean sea bass (Dicentrarchus labrax L.) phagocytes by growth hormone and parasitic status. Fish Shellfish Immunol 8:25-36

Munoz P, Alvarez-Pellitero P, Sitja-Bobadilla A (2000) Modulation of the in vitro activity of European sea bass (Dicentrarchus labrax L.) phagocytes by the myxosporean parasite Sphaerospora dicentrarchi (Myxosporea: Bilvalvulida). Fish Shellfish Immunol 10:567-581

Overstreet RM (1997) Parasitological data as monitors of environmental health. Parassitologia 39:169-175

Parry RM, Chandau RC, Sahani RM (1965) A rapid and sensitive assay of muramidase. Proc Soc Exp Biol Med 119:384-386

Romeis B (1989) Mikroskopische Technik Romeis. Urban und Schwarzenberg, Munich

Schmidt V, Zander S, Körting W, Steinhagen D (2003) Parasites of flounder (Platichthys flesus) from the German Bight, North Sea, and their potential use in biological effects monitoring. A. Infection characteristics of potential indicator species. Helgol Mar Res (in press)

Secombes CJ, White A, Fletcher TC, Stagg R, Houlihan DF (1995) Immune parameters of plaice, Pleuronectes platessa, L. along a sewage sludge gradient in the Firth of Clyde, Scotland. Ecotoxicology 4:329-340

Secombes CJ, Tahir A, Stagg RM (1997) Immunocompetence in flatfish as a measure of the biological effects of exposure to sewage sludge or hydrocarbon contaminated sediments. In: Zelikoff JT (ed) Ecotoxicology: response, biomarkers and risk assessment, an OECD workshop. SOS Publications, Fair Haven, N.J., pp 281-292

Skouras A, Steinhagen D (2003) Measuring some flounder (Platichthys flesus L.) innate immune responses to be incorporated in effect biomonitoring concepts. Helgol Mar Res (in press). DOI 10.007/s10152-003-0140-8

Skouras A, Broeg K, Dizer H, Westernhagen H von, Hansen PD, Steinhagen D (2003) The use of innate immune responses as biomarkers in a program of integrated biological effects monitoring on flounder (Platichthys flesus) from the southern North Sea. Helgol Mar Res (in press). DOI 10.007/s10152-0030141-7

Tahir A, Fletcher TC, Houlihan DF, Secombes CJ (1993) Effect of short-term exposure to oil-contaminated sediments on the immune response of dab, Limanda limanda (L.). Aquatic Toxicol 27:71-82

Yamaguti S (1959) Systema Helminthum, vol 2. The cestodes of vertebrates. Interscience, New York, 860 pp

Yamaguti S (1963a) Systema Helminthum, vol 4. Monogenea and Aspidocotylea. Interscience, New York, 699 pp

Yamaguti S (1963b) Parasitic Copepoda and Branchiura of fishes. Interscience, New York, pp 1-1104

Yamaguti S (1971) Synopsis of digenetic trematodes of vertebrates, vol 1 and 2. Keigahu, Tokyo, pp 1-1074+349 pl.

Zelikoff JT, Wang W, Islam N, Fletcher E, Twerdok LE (1997) Immune responses of fish as biomarkers to predict the health of aquatic pollution: application of laboratory assays for field studies. In: Zelikoff JT (ed) Ecotoxicology: response, biomarkers and risk assessment, an OECD workshop. SOS Publications, Fair Haven, N.J., pp 263-279

Zelikoff JT, Raymond A, Carlson E, Li Y, Beanman JR, Anderson M (2000) Biomarkers of immunotoxicity in fish: from the lab to the ocean. Toxicol Lett 112-113:325-331 